\title{
Right to health in india
}

\author{
Ramakanta Satapathy ${ }^{1 *}$, Bikram Kumar Das ${ }^{2}$ \\ ${ }^{1}$ Post Graduate Department of Law, Sambalpur University, Burla, Odisha, India, ²Department of Law, Lajpat Rai Law College, \\ Sambalpur, Odisha, India
}

Received: 26.03 .2016

Revised: 30.04 .2016

Accepted: 01.05 .2016

Published: 03.05.2016

correspondence:

Ramakanta Satapathy,

Post Graduate Department

of Law, Sambalpur University,

Odisha, India.

E-mail: rsatapathy404@

gmail.com

\section{*Address for}

Jyoti Vihar, Burla - 768019 ,

\begin{abstract}
Right to health is recognized by the Constitution of India. The Constitution of World Health Organization states that "Health is a state of complete physical, mental, and social well-being and not merely the absence of diseases or infirmity." Right to health presupposes that "it is the duty of the state to raise the level of nutrition and standard of living of the people for good health. The apex court of India declared that right to health is a fundamental right coming within Article 21 of the Indian Constitution. Right to health and health care needs multi-disciplinary services to monitor health condition of life. It is a huge task requires effective management and organized action. In this article, an attempt is made to introspect the right to health within the constitutional parameters, international provisions, and judicial decisions of Supreme Court. In this work, doctrinal method is adopted to draw the conclusion.
\end{abstract}

KEY WORDS: International conventions, protection of health right, right to health and health care, social justice and human dignity

\section{INTRODUCTION}

In a welfare, state health and health care of the people are of prime importance. It presupposes that the state to ensure conditions congenial to good health. Maintenance and improvement of public health have to rank high as these are indispensible condition required in the modern state. Right to health is a necessity for rich and poor. The right to health is concerned with various factors such as housing, food, water, sanitation, and environment. The attendance of public health, therefore, is of high priority and perhaps the one agenda at the top of the civilized nation. Adulterated fast food, sale of hazardous products, contaminated water, polluted air, unhygienic surroundings, and sanitation is now a major concern for the state. The people living in village and urban area are facing the health hazards. Thus, health service is required for the people living anywhere on the earth. UDHR, 1948, also ensures such right to the protection of basic right of human being. Health care got much significance in the world scenario. The World Health Organization (WHO) created separate agenda to provide health care. All the state parties are to support such agenda as a part of their national health planning and development. The WHO promotes sustainable health for all and cooperates with stake holders pursuing national health plans. WHO articulated ethical policy and monitoring the health condition all over the world. The Constitution of India enumerates that right to health and other related rights to be improved by the state. The states have made some effective regulatory provisions in the area of medical practice, public health care services, food control and drug administration, etc. The standard guidelines are issued by the regulatory bodies and the apex court. The high level monitoring and the apex court. The high level monitoring agencies are established to administer, control, and regulate health care units in India. Despite the fact, people of India face a lot of challenges in the area of health care. It violates the basic right of people. In this article, theoretical analysis is made to evaluate the health right of people in India. In this attempt, focus is made to analyze the various literature, committee reports, enactments and case laws. The discussion ended with conclusion and suggestion for the better and effective health services in India.

\section{INTERNATIONAL PERSPECTIVES}

Health and health care is not only a major concern for India but also in international level civilized countries are thinking and taking care of it. The Universal Declaration of Human Rights, 1948, under Article 25 
declares that "everyone has the right to a standard of living adequate for the health and well-being himself and of his family, including food, clothing, housing and medical care, and necessary social services and the right to security in the event of unemployment, sickness, disability, widow-hood, old-age, or other lack of livelihood in circumstances beyond his control." Further, it provides that "motherhood and childhood are entitled to special care and assistance. All children, whether born in or out wed-lock, shall enjoy the same special protections."

The International Covenant on Economic, Social, and Cultural Rights (ICESCR) of 1966 resolved to undertake health measure and the same was adopted by UNO in 1976. Article 12 of the covenant recognizes the right of everyone to the enjoyment of the highest attainable standard of physical and mental health. The state parties agreed to achieve the full realization of this right. It was agreed to take measure for the reduction of the still-birth and check infant mortality so that healthy development of the child can be made possible. Appropriate steps are made for the improvement of all aspects of environmental and industrial hygiene. It was resolved to take action for prevention, treatment and control of epidemic, endemic, occupational, and other diseases. The state parties shall create conditions which would assure to all medical services and medical attention in the event of sickness. Similarly, the convention on the elimination of all forms of discrimination against women ensures access of food health and education for women. The convention on the Rights of the Child provides overall development of child and health protection adolescent. International Convention on the Elimination of all forms of Racial Discrimination also give special attention on protection and advancement of health. In this regard, a number of regional treaties and instrument have been adopted to improve the working and living conditions of people and their families with a specific standard for health and dignity. It is a new global strategy to empower the population of women and adolescent from the dangers of HIV/AIDS, violence, suicide, and road traffic injuries. The WHO from time to time issuing guiding framework for domestic policies. Article 3 (1) of the regulation provides that, "the international health regulations shall be implemented with full respect for the dignity, human rights, and fundamental freedoms of persons." The international communities have given prime importance to health and health care. The "alma ata" declaration lays a special emphasis on the health facilities for all.

\section{INDIAN CONSTITUTION ON HEALTH AND HEALTH CARE}

India is a welfare state and being a signatory to UDHR adopted several health measures for health care. The Indian constitution recognized the importance of health and health care for the attainment of its socioeconomic goal. Article 21 of the Indian constitution ensures Right to Health and pollution-free environment. Article 39 (e) directs the state for the health and strength of workers, men and women, and the tender age of children are not abused and that citizens are not forced by economic necessity to enter evocation unsuited to their age or strength. Article 39 (f) provides that children are given opportunities and facilities to develop in a healthy manner and in conditions of freedom and dignity and that childhood and youth are protected against exploitation and against moral and material abandonment. Article 41 of the constitution ensures protection in old age, sickness, and disablement of the persons irrespective of their status. There are several provisions in the constitution those ensures the protection of health. Article 38, 42, 43, 47, 48 (A) of the constitution directs state for the promotion of health and strength of the people. These principles are adopted as guidelines for the state to provide just and human conditions for living. It forms the responsibility of the state to raise the level of nutrition and standard of living and improve public health and maternity relief. It becomes the constitutional obligation of the state to improve the environment for better protection of life. Under Article 51 (A), it become the fundamental duties of every citizens to protect and improve the natural environment including forest, lakes, rivers, and wild life and to have compassion for living creatures. It will foster a good condition for better health of the people.

Under seventh schedule, the states empowered to make legislation in different aspects, which will provide better health care and protection. The entries 6, 8, 17, and 51 of the state list provide that the state may make law for betterment of public health, sanitation, water supply, etc. The states are empowered to regulate production, sale, purchase, and possession of alcoholic substance and liquors. The state may make law to establish and regulate hospital, dispensaries, and medical institutions for the health care. Similarly, the entries 18, 19, 20-A of concurrent list empowers central government and state to make law to stop adulteration of foods, food stuffs, and other goods not congenial for health. Both governments have power to make regulatory measures for population control and family planning. Regulatory 
measures may be made to sale, purchase, and possession of intoxicating liquors, opium, and other narcotic substances. Article $243(\mathrm{G})$ empowers panchayats to deal with health and sanitary measure. It becomes the responsibility of panchayats to improve the health condition. The panchayats may establish and manage hospitals and dispensaries for the better health and family welfare. Under Article 243 (W), municipalities are empowered to make safety provisions for sanitation and health protection of the public. The municipality under obligations to supply water for domestic, industrial, and commercial purposes. It is the responsibility of the municipality to remove public nuisance and take steps for the improvement of slum. They are duty bound to construct drain and parks for better living. The above discussion establishes that the government is under constitutional obligation to protect the health and living condition of the people.

\section{THE JUDICIARY ON HEALTH AND HEALTH CARE}

Literally Article 21 of our constitution is a colorless article. The state has to follow the law and procedure established by law and in Article 21 has been judicially construed a meaning which is reasonable, fair and just. The stream is endless and "protection of life and liberty" is the basis of expansion of the concept of life. The Right to Health in India got its initial recognition in Francis Coralie Mullin versus Union Territory of Delhi case wherein the court held that Article 21 of the Constitution includes the basic right to food, clothing, and shelter. Mere animal existence is not the life. The Supreme Court addressed the types of conditions necessary for enjoyment of health. In Morcha case, the court held that Right to Live with human dignity also involves right to "protection of health."

Right to health includes the right to food, the reproductive rights, rights of workers to occupational health and safety, clean environment, adequate drugs, medical negligence, right against medical malpractices, emergency health care, HIV / AIDS and public health care etc., on each and above aspects the Supreme Court of India has emphasized and directed the state to take proper health measures for the welfare of the people. Some of reported cases are enumerated below.

\section{EMERGENCY HEALTH CARE}

In medical profession, it is seen that the patients either suffer or die due to non-attendance of doctors as it was their plea that they have to follow the criminal procedure code and for their safety under the law. In Paramananda Katra case, the Supreme Court observed "No legal procedures as prescribed under Cr.P.C. should act as a hindrance for a doctor to treat an emergency case and hence all the fulfillment of these legal formalities should be a secondary action and that of saving a person's life should be primary action." In an emergency case, the doctor neither examine any F.I.R given before the police nor any forward letter made by the police for medical examination. First, the doctor has to take up all reasonable treatment of the patient and later on the procedural formalities under the law shall be taken.

In a public interest litigation under Article 32 read with Article 21, the court took the practical happenings in our day to day life, where the doctors seen completing the legal formalities first then initiating the medical treatment causing serious inconveniences to the injured persons needing immediate medical treatment. The court held that preservation of human life is of paramount importance. Hence, every injured citizen brought for medical treatment should instantaneously be given medical aid to preserve life and thereafter the procedural criminal law should be followed to operate to avoid negligent death Emergency Medical treatment is the right of citizen (Katra versus Union of India, AIR 1989 SC 2039).

\section{PUBLIC HEALTH IS STATES PRIORITY}

Justice versus R. Krishna lyre, one of the leading exponent and authority on Human Rights in Municipal Council, Ratlam Case observed that the State will realize that Article 47 makes it a paramount principle of governance that the steps are taken for the improvement of public health as among its primary duties. Right to health and medical care is a fundamental right under Article $21 \mathrm{read}$ with Article 39 (e), 41 and 43.

In CESC Ltd. versus Subash Chandra Bose Case, the Supreme Court held that Right to Health is a fundamental right. "The term health implies more than an absence of sickness. Medical care and health facilities not only protect against sickness but also ensure stable man power for economic development facilities of health and medical care generate devotion and dedication to give the workers best physically as well as mentally, in productivity. It enables the worker to enjoy the fruit of his labor, to keep him physically fit and mentally alert for leading a successful economic, social, and cultural life. The medical facilities are, therefore, part of social 
security and like gilt-edged security, it would yield return in the increased production or at any rate reduce absenteeism on grounds of sickness etc. Health thus a state of complete physical, mental, and social well-being and not nearly the absence of disease or infirmity. In the light of Article 22-25 of UDHR, ICESCR, and in the light of socioeconomic justice assured in our constitution, Right to Health is fundamental human rights to workman. The maintenance of health is a most imperative constitutional goal whose realization requires interaction by many social and economic factors.

\section{ADEQUATE AND QUALITY MEDICAL CARE}

The Supreme Court of India emphasized on adequate and quality medical care. It is a part of right to health and right to life. People are entitled to adequate health care.

For adequate medical service, the Medical Council of India and the Department of Alternative Medicines such as Ayurveda, Unani, Siddha, and Homeopathy are fullfledged devoted themselves for the welfare of the people. Article 21 of the constitution casts an obligation on the State to take every measure to preserve life. It is the duty of the welfare state to ensure that medical facilities are adequate and available to provide treatment and due to the violation of the right to life of the petitioner compensation was awarded to him (Paschim Bang Khet Majdoor Samity versus State of W.B. 1996 (4) Scc. 37).

\section{HEALTH AND ENVIRONMENTAL ISSUES}

The environment plays a vital role in health of human beings, the air we breathe, water we intake, and food should not be polluted or adulterated "life, public health, and ecology have priority over unemployment and loss of revenue." It is the duty and obligation of the state give priority or public health and ecology. Right to pollution free air falls within Article 21 of the constitution for the removal of hazardous industry engaged in manufacture and sale of hazardous products at a tickly populated area causing health hazard to the workman and community living in the neighborhood, the matter was brought before the Supreme Court. The court directed to shift and relocate plant at some other place keeping in view the health care of the people of the locality. It is the duty of the state that due to contaminating source, the patients should not suffer. In an eye camp due to common contaminating source, the patients sustained damage to eyes. On humanitarian consideration directed state government to pay Rs.12,500/ - to each victim in addition to interim relief.
Enjoyment of pollution free water and air which is included in right to life. It is seen that smoking is a general practice and habit of the people in public place and adversely affect the passive smokers nearby. In a public interest litigation, the Supreme Court prohibited smoking in public places on the ground smoking is injurious to health.

Environmental pollution is linked to health and is violation of right to life with dignity. Environmental, ecological air and water pollution, etc., should be regarded as amounting to violation of right to health generated by Article 21 of the constitution. It is the obligation of the state that the citizens should enjoy their life to fullest with dignity and due to water or air pollution their life should not be disturbed. In this connection, the Supreme Court imposed an positive obligation on the state to take steps for ensuring to the individual a better enjoyment of life and dignity and for elimination of water and air pollution.

\section{WORKING PEOPLE AND HEALTH CARE}

Right to health is an integral part of a meaningful right to life. In the work places, the employees/workman face serious health hazards. In this context, special emphasis has been given under the factories Act and other legislations on the working conditions of the employees/ workman. Temperature, humidity, etc., of the work place, monotonous work, etc., plays vital role in working conditions. It is the obligation of the state not only to provide emergency medical services but also to ensure the creations of conditions necessary for good health including provisions for basic curative and preventive health services and assurance of healthy living and working conditions. In Consumer Education Research Centre case, the Supreme Court held that the right to health and medical care is a fundamental right and it makes the life of the workman meaningful and purposeful with the dignity of person. In another case, the Supreme Court held that Right to Health care of government employees is integral to right to life.

Human safety and on health the Supreme Court has always given more importance. In a public sector undertaking when the workers claimed compensation for being exposed to the ill-effects of X-ray, radiation, the court issued directions as to checks and safeguard to be adopted to guard against radiation.

\section{“MEDICAL SERVICE” AS SERVICE}

Medical service includes the diagnosis on the treatment of the disease. For medical service in return for monetary 
consideration amounts to "service" for the purpose of the Consumer Protection Act, 1986. For deficiency in service, the service provider is liable for compensation likewise in medical negligence.

\section{SALE OF COOKED FOOD ON STREETS}

It is a common sight and practice of the people to sale or intake cooked food on the streets creating permanent unhygienic conditions. In municipal areas, the municipality can stop that practice, and it is permissible under the law.

\section{HIVIAIDS CONTROL}

The Government of India prior to 2004 had only AIDs prevention policy. The treatment of the disease was not in the policy. After filing of writ petition by a voluntary Health Association of Punjab SHAP versus Union of India (W.P. No.349/2003), the Government of India announced free ARV drugs to the HIV + Ve.

\section{POVERTY AND HEALTH CARE}

Although in a number of decisions, the Supreme Court directed the state to take proper steps for providing health care but poverty is a barrier to the health service. Poverty eradication is the prime duty of a welfare state and as the poverty in India is not totally eradicated health service of the state is also not up to the mark. In this context under the chairmanship of Justice A.R. Lakshmanan, the $229^{\text {th }}$ Law Commission Report was given to the Central Government for the eradication of poverty. The main highlights of the report on health care are healthy and safe environment, adequate housing, people should be free from hunger, safe drinking water, primary health care, and medical attention in case of illness. It is the duty of the state to eradicate poverty from the country so that the Right to Health care be implemented properly. An example can be cited, the beggars home at Delhi leading a life of mere animal existence. No proper provision of drinking water, bathing, sanitation, food, clothing, and clean bedding or hygienic surroundings have been provided in the shelter home. No proper medical facilities have been provided. In Civil Writ Petition No. 117/2000, the Union of India and Government of N.C.T. were directed to take appropriate measures on right to health and health care of the beggars.

\section{CONCLUSION}

Right to Health and health care is coming within the ambit of the right to life and personal liberty. It is the obligation of the state to provide adequate and quality medical care to its people. Although the Alternative Medical People are deployed in the country, yet it has failed to cover each and every village of the country. As poverty is the root cause of the health care in India, it need to eradicated. The study reveals that poverty has not been eradicated property, the people are deprived of their right to health and health care. Further steps taken by the state for pollution control is half-hearted initiations. It is not matching with the constitutional obligation. A positive step in this regard is the need of the hour to eradicate poverty and to provide health service in the country. India has public health sector, private sector and NGO sector to provide health services to the vast and scattered population. There are international health care agencies such as Red Cross society and WHO Agencies. Government of India need to work with cooperative action and coordination among stakeholders. Apart from resources mobilization public awareness is highly necessary to reach the goal of social justice and human dignity as envisioned in the world society.

\section{REFERENCES}

Art. 3(3), 23(3), 23(4), 24 of Convention on the Rights of the Child.

Art. 5(e) (iv) of International Convention on the Elimination of all forms of Racial Discrimination (ICERD).

Art.11(1)(f), 11(2), 12, 14(2)(b) of Convention on the Elimination of all forms of Discrimination.

Available from: http://www. who.int/about/en. [Last retrieved on 2015 Nov 29].

Consumer Education Research CentreV. Union of India (1995) 3 SCC 42.

CESC Ltd. V. Subash Chandra Bose, AIR 1992 SC, 573.

Francis Coralie Mullin. V. Union Territory of Delhi 1981 (1) SCC-608.

Katra P. V. Union of India (1989) 4 SCC 286.

Law Commission of India $229^{\text {th }}$ Report under the Chairmanship of Justice A.R. Lakshman Dated 30.04.2009.

Morcha BM. V. Union of India and others AIR 1984 SC 802.

Municipal Council Ratlan V. Vardichand \& others 1980 Cr. L.J 1075. 